\title{
Rytmonorm-Induced Cytogenetic and Testicular Damage in Albino Rats: The Protective Effect of Grapefruit Juice
}

\author{
Saber A. Sakr ${ }^{1, *}$, Mohammed E. Zoail ${ }^{2}$, Samraa S. El-Shafey ${ }^{1}$ \\ ${ }^{1}$ Zoology Department, Faculty of Science, Menoufia University, Egypt \\ ${ }^{2}$ Zoology Department, Faculty of Science, Benha University, Egypt \\ *Corresponding author: sabsak@yahoo.com
}

Received December 26, 2012; Revised January 30, 2013; Accepted February 28, 2013

\begin{abstract}
The present work studied the cytogenetic and testicular damage induced by the antiarrhythmic drug rytmonorm (RT) and the protective role of grapefruit juice in albino rats. Treating rats with $\mathrm{RT}(13.5 \mathrm{mg} / \mathrm{Kg}$ bodyweight) for five weeks caused a significant increase in the percentage of chromosomal aberrations either structural or numerical and decrease the mitotic index. Using comet assays, RT caused DNA fragmentation in the lymphocytes. Testis of RT treated rats showed many histopathological and morphometric alterations. In addition, the number of sperm head abnormalities was increased. Treating animals with RT and grapefruit juice $(27 \mathrm{ml} / \mathrm{Kg}$ bodyweight) led to an improvement in chromosomal aberrations, mitotic index, DNA damage, and testicular alterations caused by RT. In conclusion, the results of this study indicated that grapefruit juice showed a protective effect on cytotoxicty and testicular alterations induced by RT in albino rats and this is may be due to its potent antioxidant effects.
\end{abstract}

Keywords: rytmonorm, grapefruit, chromosomes, comet assay, testis

\section{Introduction}

Antiarrhythmic agents including digitalis, beta-blockers and calcium channel blockers are group of pharmaceuticals that are used to suppress fast rhythms of the heart (cardiac arrhythmias) such as atrial fibrillation, atrial flutter, ventricular tachycardia and ventricular fibrillation [1,2]. The use of some antihypertensive drugs was accompanied by different side effects.

Antihypertensive drug atenolol was found to induce chromosomal aberrations (chromatid and chromosome breaks) detected as micronuclei in the peripheral lymphocytes of treated patients [3]. It also induced significant decrease in percent of progressive motility of sperm and induced significant increase in sperm head and tail abnormalities [4]. Several antihypertensive drugs currently were tested and found to promote stem mesenchymal cells apoptosis [5]. Recently, Sakr et al. ]6] reported that concor induced cytogenetic and testicular damage in albino rats. Rytmonorm or rythmol (propafenone) belongs to the class I antiarrhythmic agents which treats illnesses associated with rapid heartbeats such as ventricular and atrial arrhythmias. It works by slowing the influx of sodium ions into the cardiac muscle cells, causing a decrease excitability of the cells [7].

Many plants and plant extracts have been recommended in treatment of various illnesses. They may prevent disease, reduce the risk of developing disease or enhance general health. Grapefruit is a subtropical citrus and is an excellent source of many nutrients and phytochemicals, able to contribute to a healthy diet [8]. Grapefruit is a good source of vitamin C, and so pectin fiber [9]. Also, the pink and red hues contain the beneficial antioxidant lycopene (Lee, 2000). The seeds have high levels of antioxidant properties [10]. Grapefruit seed extract has been claimed to have strong antimicrobial properties $[11,12]$ and helps in reduction of cholesterol [13]. There is an evidence of anticancer properties of orange juice and indicate that citrus flavonoids are effective inhibitors of human breast cancer cell proliferation in vitro [14]. Naringin, abioflovnoid predominant in grape fruit and other citrus fruits, has been found to scavenge free radicals and reduce radiation induced damage such as reduction of aberrant cells and chromosomal aberrations [15]. Consumption of grapefruit juice was found to be beneficial for human health, including protection against the DNA damage [16]. The present work aims to study the possible protective effect of grapefruit juice on rytmonorm-induced cytogenetic and testicular alterations in albino rats.

\section{Materials and Methods}

\subsection{Experimental Animals}

Sexually mature male Wistar albino rats weighing 150 $\pm 10 \mathrm{~g}$ were used in the present study. Animals were kept in the laboratory under constant temperature $\left(25 \pm 3^{\circ} \mathrm{C}\right)$ throughout the experimental work. They were maintained on a standard rodent diet composed of $20 \%$ casein, $15 \%$ 
corn oil, 55\% corn starch, 5\% salt mixture and 5\% vitaminized starch (Egyptian Company of Oils and Soap, Kafr-Elzayat, Egypt). Water was available ad libitum . Maintenance of animals and experimental procedures was approved by the animal ethical committee in accordance with the guide for care and use of laboratory animals prepared by Menoufia University, Egypt. Animals were divided into 4 groups of 20 animals each:

I. First group. rats in this group served as controls.

II. Second group. Animals in this group were orally given grapefruit juice. Juice of grapefruit (Citrus paradise) was prepared by squeezing the fresh fruit. Rats were regularly orally administered with grapefruit juice at a dose level of (27ml/Kg body weight) [17].

III. Third group. Animals of this group were treated with rytmonorm. The tablet was ground and dissolved in $100 \mathrm{ml}$ distalled water. It is used at a dose level of (13.5mg/Kg body weight) modified according to therapeutic dose of human [18] and each animal were orally given $0.5 \mathrm{ml}$ containing the desired dose.

IV. Fourth group. Animals of this group were given rytmonorm $(13.5 \mathrm{mg} / \mathrm{Kg}$ body weight of rat) followed by grapefruit juice $(27 \mathrm{ml} / \mathrm{Kg}$ body weight) daily for five weeks.

\subsection{Applied Techniques}

\subsubsection{Chromosomal Preparation}

Animals were sacrificed after five weeks of treatment. Bone marrow cell preparations for analysis of chromosomal aberrations and mitotic indices were conducted by colchicines-hypotonic technique. After completion of the treatment period, five animals from each group were i.p. injected, $2 \mathrm{~h}$ before sacrifice, with $0.5 \mathrm{ml}$ colchicine $(3 \mathrm{mg} / \mathrm{kg}$ body weight), to increase the number of metaphase spreads. Bone marrow cells were collected from the femurs in isotonic $\mathrm{NaCl}$ solution and bone marrow smears were prepared. For each group, slides were stained with Giemsa and mounted in DPX. For each animal fifty metaphase spreads were scored for chromosomal aberrations. The mitotic index was obtained by counting the number of mitotic cells in 1000 cells/anima.

\subsubsection{Comet Assay}

This technique is widely used for detection of single stranded breaks. Eukaryotic cells are embedded in an agarose gel on a microscopic slide, lysed by detergents and high salt at $\mathrm{pH} 10$ and then electrophoresed for damage display which shows increased migration of the DNA from the nucleus towards the anode; this technique permits the detection and an evalution of single-stranded DNA breaks. Low-melting temperature agarose and ultra pure agarose, Triton $\mathrm{x}-100$; sodium sarcosinate; ethylenediamine-tetra acetic acid disodium salt $\left(\mathrm{Na}_{2}-\right.$ EDTA), Ttizma base and ethidiu $m$ bromide were obtained from Sigma chemical company; phosphate buffered saline (PBS), without calcium and magnesium (RBMI 1640 medium, Gibco; Ficoll separating solution and trypan-blue were used in comet assay. Examination was done with a fluorescent microscope (Olympus BX 41, Japan) equipped with an excitation filter of 510nm and barrier filter of $590 \mathrm{~nm}$. The migration was evaluated by observing and measuring the nuclear DNA and five hundred spots of DNA were examined and classified into three types: normal spots with round shape, damaged spots; in which the length of the migrated fragments is less than or equal to the diameter of the basal nuclear DNA, strongly damaged spots; where the length of the comet was greater than the diameter of the basal nuclear DNA [19].

\subsubsection{Histological Studies}

For light microscopic studies, animals were dissected and their testes were removed and fixed in $10 \%$ neutral formalin for $24 \mathrm{~h}$, washed in running tap water for $24 \mathrm{~h}$ and transferred to $70 \%$ ethyl alcohol. Tissues were dehydrated in ascending series of ethyl alcohol, cleared in xylene and embedded in wax. Sections of 5 microns thickness were cut using rotary microtome and mounted on clean slides without using any adhesive medium. Sections were stained with Ehrlich's haematoxylin and counterstained with eosin and photographed.

\subsubsection{Sperm Head Abnormalities Test}

The sperm suspension was obtained from animals by cutting the caudal epidedymis of a testis in few drops of mammalian saline. The sperm suspension was spread on clean glass slides. Sperm smears were dried in air and incubated at oven at $50^{\circ} \mathrm{C}$ overnight. The sperms were fixed in methyl alcohol and stained with haematoxylin and eosin [20].

\subsection{Statistical Analysis}

In the present work, the results are represented in tables as mean number \pm standard error. The significance of difference between the treated and normal groups was calculated used chi-square test and student's t-test.

\section{Results}

\subsection{Chromosomal Aberrations and Mitotic Index}

Chromatid deletion, chromatid fragment, chromosomal ring, centromeric attenuation of chromosomes, centric fusion of chromosomes, end to end association, chromatid gaps and chromatide breaks were recorded as structural aberrations (Table 1). Numerical aberrations such as monosomy, trisomy, tetrasomy and polyploidy were also detected (Table 2). A significant increase in structural and numerical aberrations was recorded after treatment with rytmonorm when compared with control animals. Animals given rytmonorm and grapefruit juice showed a decrease in these aberrations when compared with rytmonorm treated animals. In addition, animals treated with rytmonorm showed a decrease in the mitotic index when compared with control group. An increase in mitotix index was observed after treatment with grapefruit juice (Table $3)$. 
Table 1. Average of structural chromosomal abnormalities observed in bone marrow cells of rats treated with rytmonorm and grapefruit juice

\begin{tabular}{|c|c|c|c|c|c|c|c|c|c|}
\hline \multirow[b]{2}{*}{$\begin{array}{l}\text { Animal } \\
\text { group }\end{array}$} & \multicolumn{9}{|c|}{ Mean \pm S.E } \\
\hline & Deletion & $\begin{array}{c}\text { Chromatid } \\
\text { fragment }\end{array}$ & $\begin{array}{c}\text { Centromeric } \\
\text { attenuation }\end{array}$ & $\begin{array}{l}\text { End to end } \\
\text { association }\end{array}$ & $\begin{array}{l}\text { Centric } \\
\text { fusion }\end{array}$ & $\begin{array}{l}\text { Chromosomal } \\
\text { ring }\end{array}$ & Gaps & Breaks & Total \\
\hline control & $\begin{array}{l}10 \pm \\
0.44\end{array}$ & $\begin{array}{l}4.2 \pm \\
0.37 \\
\end{array}$ & $\begin{array}{l}0.6 \pm \\
0.24 \\
\end{array}$ & $\begin{array}{l}0.6 \pm \\
0.24 \\
\end{array}$ & $\begin{array}{c}0 \pm \\
0.00 \\
\end{array}$ & $\begin{array}{l}16 \pm \\
0.70\end{array}$ & $\begin{array}{c}0 \pm \\
0.00 \\
\end{array}$ & $\begin{array}{c}0 \pm \\
0.00 \\
\end{array}$ & $\begin{array}{l}31.4 \pm \\
1.99 \\
\end{array}$ \\
\hline Grapefruit & $\begin{array}{l}9.6 \pm \\
2.27 \\
\end{array}$ & $\begin{array}{l}16 \pm \\
1.12 \\
\end{array}$ & $\begin{array}{c}0 \pm \\
0.00\end{array}$ & $\begin{array}{l}1.2 \pm \\
0.49 \\
\end{array}$ & $\begin{array}{l}1.2 \pm \\
0.97\end{array}$ & $\begin{array}{c}16.2 \pm \\
3.30 \\
\end{array}$ & $\begin{array}{l}0.6 \pm \\
0.24 \\
\end{array}$ & $\begin{array}{c}0 \pm \\
0.00\end{array}$ & $\begin{array}{l}44.8 \pm \\
8.39 \\
\end{array}$ \\
\hline Rytmonorm & $\begin{array}{c}34.3 \pm \\
1.96 \\
\end{array}$ & $\begin{array}{l}12 \pm \\
2.00 \\
\end{array}$ & $\begin{array}{c}1 \pm \\
0.31 \\
\end{array}$ & $\begin{array}{c}1 \pm \\
0.63 \\
\end{array}$ & $\begin{array}{l}0.8 \pm \\
0.58 \\
\end{array}$ & $\begin{array}{c}23.6 \pm \\
3.31 \\
\end{array}$ & $\begin{array}{c}0 \pm \\
0.00 \\
\end{array}$ & $\begin{array}{r}1 \pm \\
0.31 \\
\end{array}$ & $\begin{array}{c}73.7 \pm \\
9.1^{*}\end{array}$ \\
\hline $\begin{array}{l}\text { Rytmonorm } \\
\text { +grape fruit }\end{array}$ & $\begin{array}{l}9.6 \pm \\
1.63 \\
\end{array}$ & $\begin{array}{l}6.8 \pm \\
0.97 \\
\end{array}$ & $\begin{array}{c}0 \pm \\
0.00\end{array}$ & $\begin{array}{c}0 \pm \\
0.00\end{array}$ & $\begin{array}{l}0.2 \pm \\
0.20 \\
\end{array}$ & $\begin{array}{c}11.4 \pm \\
2.11\end{array}$ & $\begin{array}{c}0 \pm \\
0.00 \\
\end{array}$ & $\begin{array}{l}0.2 \pm \\
0.20 \\
\end{array}$ & $\begin{array}{c}28.2 \pm \\
5.11 \\
\end{array}$ \\
\hline
\end{tabular}

(*). Statistically significant $(\mathrm{P}<0.05)$

Table 2. Average of numerical chromosomal abnormalities observed in bone marrow cells of rats treated with rytmonorm and grapefruit juice

\begin{tabular}{|c|c|c|c|c|c|}
\hline \multirow{2}{*}{ Animal group } & \multicolumn{5}{|c|}{ Mean \pm S.E } \\
\cline { 2 - 6 } & Monosomy & Trisomy & Tetrasomy & Polyploidy & Total \\
\hline control & $4 \pm 0.31$ & $0 \pm 0.00$ & $0 \pm 0.00$ & $0.4 \pm 0.24$ & $4.4 \pm 0.55$ \\
\hline Grapefruit juice & $6 \pm 1.18$ & $0.6 \pm 0.24$ & $0.4 \pm 0.24$ & $1 \pm 0.31$ & $8 \pm 1.97$ \\
\hline Rytmonorm & $12.8 \pm 1.02$ & $1 \pm 0.31$ & $1 \pm 0.31$ & $1 \pm 0.31$ & $15.8 \pm 1.95^{*}$ \\
\hline Rytmonorm + grapefruit juice & $10.6 \pm 1.69$ & $1.2 \pm 0.73$ & $0.2 \pm 0.20$ & $0.2 \pm 0.20$ & $12.2 \pm 2.82$ \\
\hline
\end{tabular}

\subsection{Detection of DNA Damage of Single Strand Breaks by Comet Assay}

The results showed that animals treated with rytmonorm showed a significant increase in DNA fragmentation appeared as damaged and strongly damaged spots while animals given grapefruit juice showing improvement in DNA by decreasing the number of damaged and strongly damaged spots as detected by comet assay(Figure 1 and Table 4).

Table 3. Mean value of mitotic index in bone marrow cells of rats treated with rytmonorm and grapefruit juice

\begin{tabular}{|c|c|}
\hline Animal group & Mean \pm S.E \\
\hline Control group & $709 \pm 2.59$ \\
\hline grapefruit juice & $683 \pm 2.62$ \\
\hline Rytmonorm & $578 \pm 3.18^{*}$ \\
\hline Rytmonorm+ grapefruit juice & $600 \pm 3.75$ \\
\hline
\end{tabular}

(*). Statistically significant $(\mathrm{P}<0.05)$

Table 4. Mean value of DNA damage detected by comet assay in rat lymphocytes treated with rytmonorm and grapefruit juice

\begin{tabular}{|c|c|c|c|c|}
\hline Animal group & $\begin{array}{c}\text { Normal } \\
\text { cells }\end{array}$ & $\begin{array}{c}\text { Damaged } \\
\text { cells }\end{array}$ & $\begin{array}{c}\text { Strongly } \\
\text { damaged } \\
\text { cells }\end{array}$ & $\begin{array}{c}\text { Total } \\
\text { damaged } \\
\text { cells }\end{array}$ \\
\hline control & $97 \pm 0.83$ & $3 \pm 0.83$ & 0 & $3 \pm 0.83$ \\
\hline $\begin{array}{c}\text { Grapefruit } \\
\text { juice }\end{array}$ & $95 \pm 1.09$ & $5 \pm 1.09$ & 0 & $5 \pm 1.09$ \\
\hline Rytmonorm & $90 \pm 1.41$ & $9 \pm 1.00$ & $1 \pm 0.44$ & $10 \pm 1.44^{*}$ \\
\hline $\begin{array}{c}\text { Rytmonorm + } \\
\text { grapefruit juice }\end{array}$ & $96 \pm 0.70$ & $4 \pm 0.70$ & 0 & $4 \pm 0.70$ \\
\hline
\end{tabular}

(*). Statistically significant $(\mathrm{P}<0.05)$

\subsection{Histological Observation}

The typical features of normal seminiferous tubules, spermatogenic cells, intertubular connective tissue and spermatozoa were appeared in sections of testis of control rat (Figure 2). The same histological structure was shown in sections of animals given grapefruit juice for five weeks. Sections from animals administrated with rytmonorm showed irregular seminiferous tubules with a decrease of spermatogenic cells (Figure 3) and the interstitial tissue was degenerated. Sections of testis of animals administered rytmonorm and grapefruit juice revealed less prominent histopathological alterations. Most of the seminiferous tubules appeared with increased spermatogenic layers and increase of sperm bundles (Figure 4).
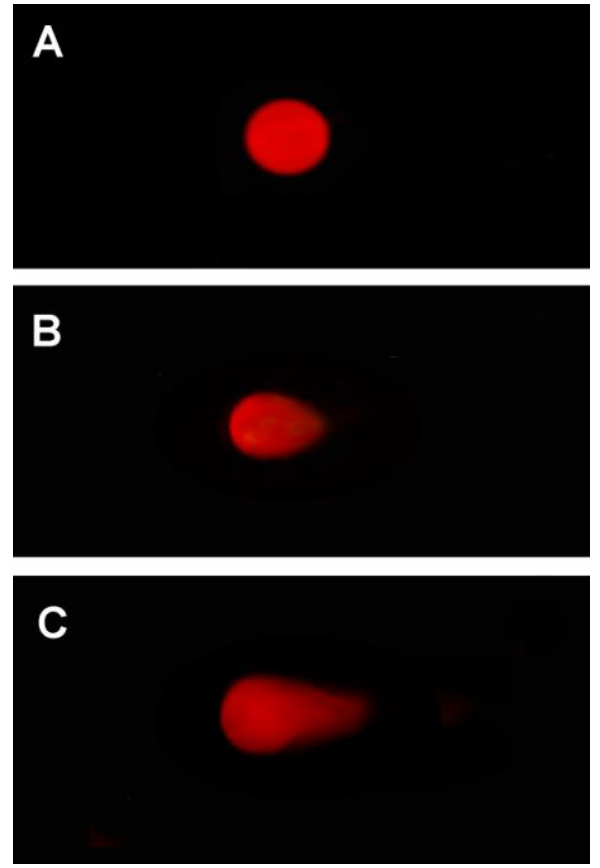

Figure 1. Photomicrograph showing single strand breaks (comet assay)) of DNA of rat lymphocytes. (A) Normal DNA spots (no migration). (B) Damaged DNA spots (migration towards the anode), (C) Strong damaged DNA spots (more migration towards the anode)

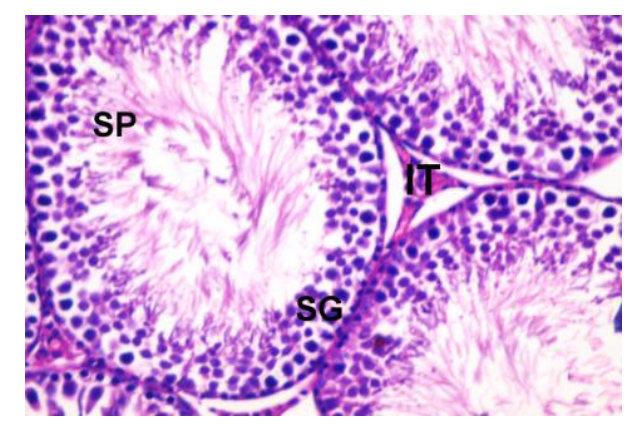

Figure 2. Section in testis of rat showing A: Normal seminiferous tubules spermatogenic cells (SG), intertubular connective tissue (It) and spermatozoa (SP) (H\&E X400) 


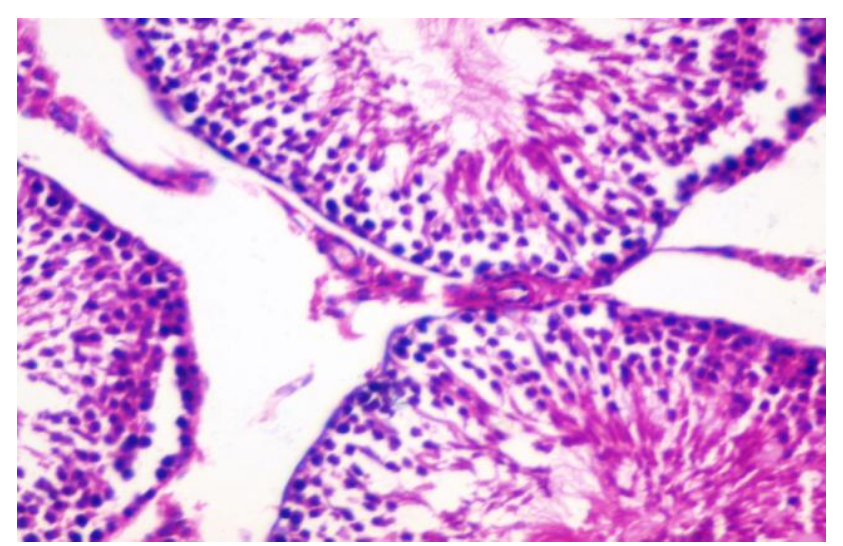

Figure 3. Section in testis of rat treated with rytmonorm showing irregular seminiferous tubules with degenerated interstitial tissues (X400)

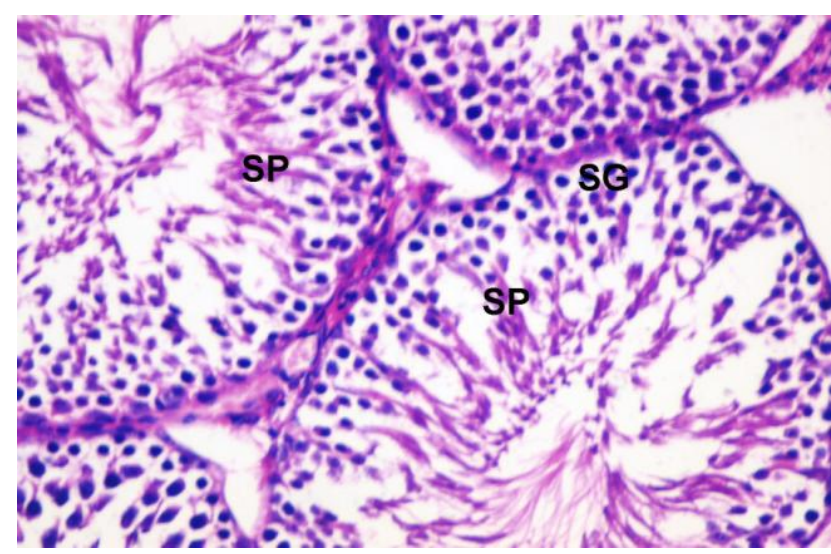

Figure 4. Section in testis of a rat given rytmonorm with grapefruit juice showing an improvement in histological appearance of spermatogenic cells (SG) and spermatozoa (SP) (X400)

\subsection{Morphometric Results}

A decrease in diameter of seminiferous tubules and germ cell height of seminiferous tubules was recorded in rytmonorm-treated rats in compare with normal ones. Animals treated with rytmonorm and grapefruit juice showed marked improvement in the mean tubular diameter and in germ cell height in comparison with rytmonorm treated animals (Table 5).

Table 5. Mean value of the diameter and epithelial height of seminiferous tubules in rats treated with rytmonorm and grapefruit juice

\begin{tabular}{|c|c|c|}
\hline Animal group & $\begin{array}{c}\text { Diameter } \\
\text { (Mean } \pm \text { S.E) }\end{array}$ & $\begin{array}{c}\text { Epithelial height } \\
\text { (Mean } \pm \text { S.E) }\end{array}$ \\
\hline control & $405 \pm 13.22$ & $129 \pm 3.5$ \\
\hline Grapefruit juice & $388 \pm 10.19$ & $128 \pm 2.7$ \\
\hline $\begin{array}{c}\text { Rytmonorm } \\
\text { Rytmonorm + grapefruit } \\
\text { juice }\end{array}$ & $360 \pm 6.32 *$ & $80 \pm 6.32 *$ \\
\hline
\end{tabular}

(*). Statistically significant $(\mathrm{P}<0.05)$

\subsection{Sperm Head Abnormalities}

The result indicated that there was an increase in the mean number of sperm head abnormalities (without hock, banana type, amorphous, hummer shape) in animals treated with rytmonorm. Treating animals with grapefruit juice caused a significant decrease in sperm head abnormalities (Table 6).
Table 6. Effect of rytmonorm and grapefruit juice on sperm head abnormalities

\begin{tabular}{|c|c|c|c|c|c|}
\hline Animal group & $\begin{array}{l}\bar{\Xi} \\
\text { हే } \\
\text { Z }\end{array}$ & 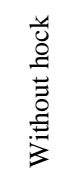 & 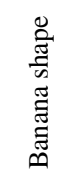 & 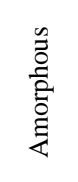 & 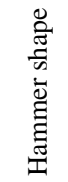 \\
\hline Normal control & $\begin{array}{l}998.4 \pm \\
0.50\end{array}$ & $\begin{array}{l}1.2 \pm \\
0.37\end{array}$ & $\begin{array}{l}1.2 \pm \\
0.20\end{array}$ & 0 & 0 \\
\hline Grapefruit juice & $\begin{array}{c}994.2 \pm \\
1.39\end{array}$ & $\begin{array}{c}2.6 \pm \\
0.81\end{array}$ & $\begin{array}{l}1.8 \pm \\
0.37\end{array}$ & $\begin{array}{c}0.6 \pm \\
0.24\end{array}$ & 0 \\
\hline Rytmonorm & $\begin{array}{c}983.8 \pm \\
0.86\end{array}$ & $\begin{array}{l}8.8 \pm \\
0.86^{*}\end{array}$ & $\begin{array}{l}5.6 \pm \\
0.87 *\end{array}$ & $\begin{array}{l}1.6 \pm \\
0.40^{*}\end{array}$ & $\begin{array}{c}1 \pm \\
0.31 *\end{array}$ \\
\hline $\begin{array}{l}\text { Rytmonorm + } \\
\text { grapefruit juice }\end{array}$ & $\begin{array}{l}993 \pm \\
1.41\end{array}$ & $\begin{array}{l}4.8 \pm \\
0.66\end{array}$ & $\begin{array}{l}2.4 \pm \\
0.51\end{array}$ & $\begin{array}{l}0.6 \pm \\
0.24\end{array}$ & 0 \\
\hline
\end{tabular}

(*). Statistically significant $(\mathrm{P}<0.05)$

\section{Discussion}

The present study showed that animals given rytmonorm showed an increase in the mean number of structural chromosomal aberrations including chromatide deletion, chromatide fragments, chromosomal ring, centromeric attenuation of chromosomes, centric fusion of chromosomes, end to end association of chromosomes, chromatid gaps and breaks. Numerical aberrations (monoploidy, triploidy, tetraploidy and polyploidy) and mitotic index also decreased by the treatment with this drug. Similarly, Telez et al. [3], showed that the antihypertensive drug atenolol was found to induce chromosome loss. Krishnamurthy and Aruna [21], stated that antihypertensive drug, propranolol induce significant chromosomal aberrations at any dose tested. DNA fragmentation was observed in lymphocytes of animals treated with rytmonorm. Isomoto et al. [22], reported that antiarrhythmic, amiodarone induced DNA fragmentation in culture H9c2 cells. Maier and Schawalder (23), showed that after exposure to doxorubicin, nitrofurantoin, propranolol and practolol at a low dose, tissue oxygen concentration $\left(5 \% \mathrm{O}_{2}\right)$, cell cycle kinetics, DNA and the protein content of G1-phase cells (nucleus/cytoplasm ratio) were decreased. An increase in sperm head abnormalities was observed in animals given rytmonorm. El-Sayed et al. [4], reported that atenolol, metoprolol and propranolol have a toxic effect on male fertility and induced significant decrease in percent of progressive motility of sperm besides increase in sperm head and tail abnormalities and cause a significant decrease in the level of testosterone hormone at first and 30 days after the last dose. Khan et al. [24], reported that patients taking betablockers experience sexual dysfunction. Anakwe et al. [25], reported that rodent Leydig cells possess betaadrenergic binding sites and point out a possible dissociation between receptor recognition and physiologic response.

Treating rats with rytmonorm and grapefruit juice showed a protection against rytmonorm -induced cytogenetic and testicular abnormalities. The protective effects of grapefruit were studied by many investigators. Attia [26] studied the anti-mutagenic effects of naringin, a grapefruit flavonone, against lomefloxacin-induced genomic instability in vivo in mouse bone marrow cells by chromosomal aberration assays. Miyata et al. [27], stated that rats allowed free access to grapefruit juice for 5 days prior to AFB1 administration resulted in clearly reduced 
DNA damage in liver. Alvarez-González et al. (16), reported that the consumption of grapefruit juice has been associated with various activities potentially beneficial for human health, including protection against the DNA damage produced by various compounds. They found that grapefruit juice inhibited the rate of micronucleated polychromatic erythrocytes and sister chromatid exchanges induced by the antineoplastic alkylating agent ifosfamide. Alvarez González et al. [28], reported that grapefruit juice is widely consumed in many countries and several of its constituents possess nutritive value, as well as antigenotoxic and antioxidant effects. So et al. [14], reported that citrus flavonoids are effective inhibitors of human breast cancer cell proliferation in vitro. Miyata et al. [29], studied the influence of grapefruit juice intake on 2-amino-1-methyl-6-phenylimidazo[4,5-b]pyridine (PhIP)induced colon DNA damage and found that grapefruit juice suppresses PhIP-induced colon DNA damage by a mechanism independent of PhIP absorption in the intestine. Jagetia et al. [15], reported naringin, a bioflovnoid predominant in grape fruit and other citrus fruits, has been found to scavenge free radicals and reduce radiation induced damage such as reduction of aberrant cells and chromosomal aberrations like acentric fragments, chromatid and chromosome breaks, centric rings, dicentrics and exchange.

Antioxidants are known to scavenge free radicals thereby decreasing the degree of the effects of many harmfull drugs and chemicals. The antioxidant activity of grapefruit components was studied. Girennavar et al. [30], isolated two bioactive compounds from grapefruit juice and grapefruit peel oil. Structures of the compounds were identified as bergaptol and geranylcoumarin. bergaptol showed very good radical scavenging activity at all the tested concentrations. Furthermore, these compounds were found to be potent inhibitors of debenzylation activity of CYP3A4 enzyme. Guimarães et al. [31], studied a comparison between the antioxidant properties of peel (flavedo and albedo) and juices of citrus fruit (Rutaceae), grapefruit (Citrus paradisi), lemon (Citrus limon), lime (Citrus xaurantiifolia) and sweet orange (Citrus sinensis) and found that phenolics were the main antioxidant compounds found in all the extracts. The dominant flavanone glycoside in grapefruit is naringin. Naringin has been found to scavenge free radicals that reduce radiationinduced damage [15]. Thus, it is concluded from the present work that the protective effect of grapefruit juice may be attributed to its antioxidant activity.

\section{References}

[1] Nichol, G.; McAlister, F.; Pham, B.; Laupacis, A.; Shea, B.; Green, M.; Tang, A. and Wells, G., Meta-analysis of randomised controlled trials of the effectiveness of antiarrhythmic agents at promoting sinus rhythm in patients with atrial fibrillation. Heart, 87(6): 535-543, 2002.

[2] Wyse, D.; Waldo, A.; DiMarco, J.; Domanski, M.; Rosenberg, Y.; Schron, E.; Kellen, J.; Greene, H.; Mickel, M.; Dalquist, J. and Corley, S., A comparison of rate control and rhythm control in patients with atrial fibrillation. N. Engl. J. Med., 347(23): 18251833, 2002.

[3] Télez, M.; Ortiz-Lastra, E.; Gonzalez, A. J.; Flores, P.; Huerta, I.; Ramírez, J. M.; Barasoain, M.; Criado, B. and Arrieta, I., Assessment of the genotoxicity of atenolol in human peripheral blood lymphocytes: correlation between chromosomal fragility and content of micronuclei. Mutat. Res., 695(1-2): 46-54, 2010.
[4] El-Sayed, M. G.; El-Sayed, M. T.; Elazab A. S.; Hafeiz, M. H., ElKomy , A. A. and Hassan, E., Effects of some beta-adrenergic blockers on male fertility parameters in rats. Dtsch Tierarztl Wochenschr., 105(1): 10-12, 1998.

[5] Stead, S.; Werstiuk, E. S. and Lee, R. M., Nifedipine induces apoptosis in cultured vascular smooth muscle cells from spontaneously hypertensive rats. Life Sci., 67(8): 895-906, 2000.

[6] Saber A. Sakr, Mohammed E. Zowail, Samraa S. El-Shafey, Ameliorative effect of grapefruit juice on amiodarone-induced cytogenetic and testicular damage in albino rats. Asian Pacific J.Trop. Biomed. 2012.(In press)

[7] Trevor; Anthony, J.; Katzung and Bertram, G., Pharmacology. New York: Lange Medical Books/McGraw-Hill, Medical Publishing Division. 2003.

[8] Fellers, P. J.; Nikdel, S.; Lee, H. S., Nutrient content and nutrition labeling of several processed Florida citrus juice products. J. Am. Diet Assoc., 90 (8): 1079-1084, 1990.

[9] Cerda, J. J.; Robbins, F. L.; Burgin, C. W.; Baumgartner, T. G.; Rice, R. W., The effects of grapefruit pectin on patients at risk for coronary heart disease without altering diet or life style. Clin. Cardiol., 11(9): 589-594, 1998.

[10] Armando, C.; Maythe, S. and Beatriz, N. P., Antioxidant activity of grapefruit seed extract on vegetable oils. J. Sci. of Food, Agric., 77(4): 463-467, 1997.

[11] Takeoka, G. R.; Dao, L. T.; Wong, R. Y. and Harden, L. A., Identification of benzalkonium chloride in commercial grapefruit seed extracts. J. Agric. Food Chem., 53(19): 7630-7636, 2005.

[12] Ganzera, M.; Aberham, A. and Stuppner, H., Development and validation of an HPLC/UV/MS method for simultaneous determination of 18 preservatives in grapefruit seed extract. $J$. Agric. Food Chem., 54(11): 3768-3772, 2006.

[13] Platt, R., Current concepts in optimum nutrition for cardiovascular disease. Prev. Cardiol., 3(2): 83-87, 2000.

[14] So, F. V.; Guthrie, N.; Chambers, A. F.; Moussa, M. and Carroll, K. K., Inhibition of human breast cancer cell proliferation and delay of mammary tumorigenesis by flavonoids and citrus juices, 26(2): 167-181, 1996.

[15] Jagetia, G. Ch.; Venkatesha, V. A. and Reddy, T. K., Naringin, a citrus flavonone, protects against radiatin- induced chromosome damage in mouse bone marrow. Mutagenesis, 18(4): 337-343, 2003.

[16] Alvarez-González, I.; Madrigal-Bujaidar, E. and Sánchez-García, V. Y., Inhibitory Effect of Grapefruit Juice on the Genotoxic Damage Induced by Ifosfamide in Mouse. Plant Foods Hum Nutr. 65(4): 367-373, 2010.

[17] 17.El-Lakkany, N. M.; Seif el-Din, S. H.; Badawy, A. A. and Ebeid, F. A., Effect of artemether alone and in combination with grape fruit juice on hepatic drug-metabolising enzymes and biochemical aspects in experimental Schistosoma mansoni. Int. J. of parasitol., 34(12): 1405-1412, 2004.

[18] Paget, G. E. and Barnes, J. M., Toxicity tests in evaluation of drug activities pharmacometries (Laurence, D. R. and Bacharach, A. L. eds) Academic Press, London and New York, 1964.

[19] Singh, N. P.; McCoy, M. T.; Tice, R. R. and Schneider, E. L., A simple technique for quantitation of low levels of DNA damage in individual cells. Exp. Cell Res., 175: 184 -191, 1988.

[20] Wyrobek, A. J. and Burce, W. R. (1975): Chemical introduction of sperm abnormalities in mice. Proc. Nat. Acad. Sci. USA., 72(11): 4425-4429.

[21] Krishnamurthy, N. B. and Aruna, N., Mutagenic evaluation of propranolol in somatic and germ cells of mice. Mutat. Res., 173(3): 207-210, 1986.

[22] Isomoto, S.; Kawakami, A.; Arakaki, T.; Yamashita, S.; Yano, K. and Ono, K., Effects of antiarrhythmic drugs on apoptotic pathways in H9 c2 cardiac cells. J Pharmacol. Sci., 101(4): 318324, 2006.

[23] Maier, P. and Schawalder H., Alterations in the cellular DNA and protein content determined by flow cytometry as indicators for chemically induced structural and numerical chromosome aberrations. Mutagenesis, 3(3): 219-226, 1988.

[24] Khan, U. A.; Aslam, M. and Saeed, S. A., Effect of beta adrenergic antagonist on the production of testosterone by rat's Leydig cells. J. Ayub. Med. Coll. Abbottabad, 16(4): 26-28, 2004.

[25] Anakwe, O. O.; Murphy, P. R. and Moger, W. H., Characterization of beta-adrenergic binding sites on rodent Leydig cells. Biol. Reprod., 33(4): 815-826, 1985.

[26] Attia, S. M., Abatement by naringin of lomefloxacin-induced genomic instability in mice. Mutagenesis, 23(6): 515-521, 2008. 
[27] Miyata, M.; Takano, H. Q.; Guo, L.; Nagata, K. and Yamazoe, Y., Grapefruit juice intake does not enhance but rather protects against aflatoxin B1-induced liver DNA damage through a reduction in hepatic CYP3A activity. Carcinogenesis, 25(2): 203-209, 2004.

[28] Alvarez-Gonalez, E.; Madrigal-Bujaidar, L.; Martino-Roaro, J. J and Espinosa-Aguirre, Antigenotoxic and antioxidant effect of grape fruit juice in mice treated with daunorubicin, Toxicol. Lett., 152(3): 203-211, 2004

[29] Miyata, M.; Takano, H.; Takahashi, K.; Sasaki, Y. F. And Yamazoe, Y., Suppression of 2-amino-1-methyl-6- phenylimidazo[4,5-b]pyridine-induced DNA damage in rat colon after grapefruit juice intake. Cancer Lett., 183(1): 17-22, 2002.

[30] Girennavar, B.; Jayaprakasha, G. K.; Jadegoud, Y.; Nagana Gowda, G. A. and Patil, B. S., Radical scavenging and cytochrome P450 3A4 inhibitory activity of bergaptol and geranylcoumarin from grapefruit. Bioorg Med. Chem., 15(11): 3684-3691, 2007.

[31] Guimarães, R.; Barros, L.; Barreira, J. C.; Sousa, M. J.; Carvalho, A. M. and Ferreira, I. C., Targeting excessive free radicals with peels and juices of citrus fruits: grapefruit, lemon, lime and orange. Food Chem. Toxicol., 48(1): 99-106, 2010. 